\title{
The Implementation of Reading Text Strategies in Enhancing EFL Learners Vocabularies: A Case of One Islamic Higher Education in Jambi, Indonesia
}

Received: 02-08-2021; Revised: 27-10-2021 ; Accepted: 01-11-2021

Toni Indrayadi *)

Institut Agama Islam Negeri Kerinci, Jambi, Indonesia

E-mail: penulis1@gmail.com

*) Corresponding Author

\begin{abstract}
The purpose of this study was to reveal the lecturer's strategy in enhancing students' English vocabularies in the process of teaching and learning in the classroom. 3 English lecturers who have ever taught English for Academic Purposes (EAP) in non-English department were involved in this study. The data were collected through semi-structure interview. Thematic analysis was applied for analysis the participants' interview result. Finding of this study show that; first. the participants used selected reading text as a media of enhancing students vocabularies. Second, the strategy was implemented through small group discussion and pair work to make students actively participated in sharing the knowledge. Third, the participants evaluated the students' understanding of reading text strategy by asking them to work individually without any assistance from the group members This study recommended that the findings can be a basis consideration in enhancing students' vocabularies in the process of teaching and learning.
\end{abstract}

Abstrak: Tujuan dari penelitian ini adalah untuk mengungkap strategi dosen dalam meningkatkan kosakata bahasa Inggris mahasiswa dalam proses belajar mengajar di kelas. 3 dosen bahasa Inggris yang pernah mengajar English for Academic Purposes (EAP) di jurusan non-Bahasa Inggris terlibat dalam penelitian ini. Pengumpulan data dilakukan melalui wawancara semi-struktur. Analisis tematik digunakan untuk menganalisis hasil wawancara partisipan. Temuan penelitian ini menunjukkan bahwa; pertama. peserta menggunakan teks bacaan pilihan sebagai media peningkatan kosakata siswa. Kedua, strategi yang diterapkan melalui diskusi kelompok kecil dan kerja berpasangan membuat siswa berpartisipasi aktif dalam berbagi pengetahuan. Ketiga, peserta mengevaluasi pemahaman siswa tentang strategi membaca teks dengan meminta mereka untuk bekerja secara individu tanpa bantuan dari anggota kelompok. Penelitian ini merekomendasikan bahwa temuan tersebut dapat menjadi dasar pertimbangan dalam meningkatkan kosakata siswa dalam proses belajar mengajar.

Keywords: Lecturers'strategies, EFL Learners' Vocabularies, Case study 


\section{INTRODUCTION}

$\mathrm{T}$ The strategy related to enhanching enhancing students' vocabulary have been conducted by several by reseachers (Hidayat, 2016; Kusumaningrum \& Pertiwi, 2020; Noviyanti et al., 2019; Santoso \& Andriyadi, 2019; Sari et al., 2019; Syafrizal \& Haerudin, 2018).

Hidayat (2016) conducted the study of using game strategy to improve students' vocabulary. The study was applied in a classroom action which involved 38 students of seven grades students in junior high schools in Gresik which comprised of 28 male, and 10 female. The study finding showed that the students' average score was increased from 57.6 in pre-test and 85.2 in post-test. It indicated that there was improvement of the students' vocabulary average score after teaching through game.

Kusumaningrum and Pertiwi (2020) revealed that there was improvement of the students' average score from cycle to cycle and in post-test after receiving Plickers treatment used by the lecturer in the process of teaching and learning. The study was conducted through classroom action research that involved 24 students of Electrical Avionic Study Program at STT Adisutjipto Yogyakarta as the sample.

Accordingly, Noviyanti et al (2019) who conducted the research entitled "The Use of Think Bingo Game to Improve Students' Vocabulary Mastery" using experimental method. They involved 100 students of second-grade students of SMPN 16 Banda Aceh as the sample of the study. The data analysis showed that there were a significance different average score of students of experiment class that received Think Bingo Game compared to control class in post-test. There was significance increasing score of experiment class from pre-test to post-test.

Santoso and Andriyadi (2019) on their research entitled "The Use of My Dictionary Application to Improve Students' Vocabulary Mastery" using quasiexperimental design at one MTs Darunadwah Cipongkor Kabupaten Bandung
Barat revealed that the students IX A as experiment class got higher score in post-test after receiving My Dictionary Application compare IX B as control group.

Moreover, Sari et al (2019) who conduct a Classroom Action Research on "Improving Students' Vocabulary Mastery Using English Song". The study was conducted to 30 students of of class X-Nursing in academic year of 2018/2019 at SMK Wirasaba Karawang which comprise of 20 females and 10 males. The study found that there was an improvement of the students from cycle 1 to cycle 2 after taught through song in the process of teaching and learning. The average score in cycle 1 was 67.33 and Cycle II was 83.7.

A study on building vocabulary strategy conducted by Syafrizal and Haerudin (2018) to seventh grade students and the teachers who taught vocabulary at pesantren Daar elqolam through qualitative design. The study revealed that the teaching vocabulary technique use by teachers in teaching vocabulary was translation, memorization, playing games and sing a song and used picture, real things, and student's English book as the teaching media.

The findings of the several studies above showed that teaching strategy were able to enhance the students' vocabulary using certain media. However, in this study, the researcher tried to investigate the implementation of reading text as the strategy in enhancing the students' vocabularies in the process of teaching and learning. This study will provide information for English lecturers about teaching strategy in enhancing students' vocabulary in the process of teaching and learning. The following research questions were used to guide this study: (1) How do lecturers implement reading text strategies in enhancing EFL learners' vocabularies? (2) How do lecturers evaluate vocabularies improvement?

\section{METHOD}

The procedure of qualitative research employed in this study is case study 
approach. A case study approach was adopted in this study since it attempts to investigate and understand human issues in a particular group (Harrison et al., 2017). (Kumar, 2011) briefly stated that case study can be a basis of finding what a researcher wants to find in a case. Specifically, this type of qualitative research attempt to investigate case of classroom activities.

The case of this study is the lecturers' strategies in enhancing students' vocabulary. Three lecturers of English department were selected as the participants based on convenient sampling since the participants are the researcher's friend who teaches English for academic purposes (EAP) at English non-English department. Convenience refers to sample who are easily contacted (Etikan et al., 2016). In this study, the participants were 3 English department lecturers at one state Islamic higher education institution, Jambi Indonesia.

The data were gathered through semi structured interview along March until June 2019. This type of interview is used when the researcher wants to delve deeply into a topic and to understand thoroughly the answers provided (Harrell \& Bradley, 2009). Choosing this technique is based on the consideration that this interview type are more suitable answer research question related the study topic. The researcher was also able to get the information deeply through this interview, because the interview question can be developed by the researcher based on the interview guide provided in the research. To gain the valid data, I conducted face to face interview for each participants in the placed promised based on the agreement as stated by (Mukminin \& McMahon, 2013), in-depth interviews are usually conducted face-to-face and involve one interviewer and one participant. However, as the interviewer the researcher must be able to engage with the participants by asking in neutral way, listening the participants answer attentively, then asking follow-up question based on the participants' answers, and encouraging participants to provide particular answers (Mack et al., 2005).
A thematic analysis was used in analyzing participants' interview in several steps. First, the recorded data was labeled based on each participant's pseudonyms. Secondly, the interview results were listened for several times for the accuracy. Thirdly, the researchers transcribed each participant's interview result. Afterward, the transcripts were reread line-by-line several times to obtain overall views about lecturers' strategy in enhancing the students' vocabularies, then, identified and coded. Finally, we started to cluster the categorizing code into themes to help us to explain the research questions. Hilal and Al Abri (2013) viewed that code is combination of words, phrases, and sentences chunk of the interview entire the paragraph. However, the overlapping and repetitive data were removed during this process. The categorizing code themes were then translated into English.To ensure the trustworthiness of the study, firstly the researcher masked the participants' identity to maintain their confidentiality in expressing their views. Second, the researchers arranged the interview questions based on themes of the study. Third, the researchers provided the copies of interview for member-checking by involving all participants to ensure the views of participants not misprinted. Finally, the researchers code and identify research themes to present the research question. No conflict of interest this study, despite the author being English lecturers at the Islamic higher education institution where the research conducted, I work professionally.

\section{RESULTS AND DISCUSSION \\ Results}

Two research questions were analyzed in this study as mentioned previously by asking participants to explain the implementation of reading text strategy in teaching vocabulary, and evaluation of vocabulary improvement as seen in the following: 
How do lecturers implement reading text strategies to enhance EFL learners' vocabularies?

All participants build the students' vocabulary by asking the students to underline certain words in reading text. Underlining certain words can make the students understand words formation and enrich their vocabularies. In this case, the participants also asked the students to work cooperatively with group members based on the National Qualification Framework (KKNI) as the curriculum of higher education which focused on students' activeness in the process of teaching learning. They stated:

"I asked the students to underline the words based on their part of speech by cooperatively worked in group. Hopefully, by doing this the students can understand words formation process". (EL1).

"Firstly, I divided the students into some small groups in order they can sharing the knowledge each other when underlining certain words based on the part of speech. Moreover, I instructed them to identify prefixes and suffixes in main words". (EL2).

On the contrary, EL3 did differently in enhancing students' vocabulary. He only asked the students identify words based on the part of speech by working in groups. He said:

"I instructed them to identify words based on the part of speech working in pairs. I considered that working in group can make the students actively participated in the learning activities". (EL3)

However, after underlining and identifying words based on the part of speech. Each participant explained the students about how the words are formed. They stated:

"I explain the students about how the words are formed after they underlined certain words in a reading text." It is started by explaining the verbs ended in -s/-es and-ing form". (EL1)
"After the students worked in group, I explained them about main verb, noun, and adjective and how to add prefixes and suffixes". (EL2)

"Explaining about words formation in term of suffixes and prefixes were done after the students work in group. It is as the way to make the students to understand words formation in detail".

(EL3)

These views show that the participants attempt to make the students actively involved in the learning activities with using underlining and words identification based on the part of speech by working in groups and pairs. This strategy brought the students to understand words formation.

\section{How do lecturers evaluate Students Understanding of reading text strategy implementation?}

Evaluating the students' understanding of reading strategy is very important in the teaching and learning process. It is as an evaluation of strategy understanding. All participants evaluate the students' understanding by asking them to identify and undersline certain words.

"I evaluated the students' understanding in implementing reading text strategy by asking each of them to underline words based on part of speech and explain the affixation process". (EL1)

"The students were asked to underline words based on part of speech in reading text, then explained how affixation can change the meaning every meeting ". (EL2)

'I gave different text to students' then asked them to explain the words which have got prefixes and suffixes". (EL3).

"I asked each student to identify and underline affixes in a text, then explain the process without working with other students in group.

It can be seen in the interview result that each participant evaluated the students' understanding of reading text implementation for engancing mastery by 
asking them to work individually without any assistance from their group members.

\section{Discussion}

The result of current study provides information about the lecturers' strategy in enhancing students' vocabularies in the process of teaching and learning at one Islamic higher education institution in Jambi, Indonesia.

Teaching strategies refer to a teacher taking decision to facilitate students in the process of teaching and learning (Orlich et al., 2009). Accordingly, (Aini \& Azizah, 2019) briefly stated that teaching strategy is the use of varieties method in increasing the learning quality as the teaching and learning process objective. The importance of teaching strategies in enhancing students' performance was also stated by (Kangu, 2015), he found that teaching strategies influence the students' performance in process of teaching and learning. But, achieving students' performance as the learning objective the lecturers must be able to firstly engage students in learning in the teaching and learning activities. (Han, 2021) who conducted the research entitle "The Relations between Teaching Strategies, Students' Engagement in Learning, and Teachers' Self-Concept" revealed that feedback, scaffolding, active learning, and collaborating impact on students' learning engagement in learning activities.

This study revealed that in implementing reading text to enhance students vocabularies, all participants taught the students to identify words based on the part of speech in the process of teaching and learning. In, doing so, the students were divided into some groups discussion to ease them sharing they knowledge with their group members or pairs. It was also found in the findings that the students were let to work individually without any helping from their group members in using reading text strategy to find certain words by underlining them.

This study findings is consistence with (Meliana et al., 2018), they found that teachers of Sultan Agung Sumber taught vocabularies through text. The teachers asked the students to read and translated certain words for deep comprehension of the text content.

Accordingly, (Ramadhan et al., 2021), the conducted the research entitled " Enhancing EFL Learners' Reading Vocabulary Acquisition through Task-Based Instruction". They used two kinds of report texts related Indonesian culture in teaching vocabulies which taught in. They found that work collaboratively encourage the students to master vocabularies.

Using text in teaching vocabulary was also conducted by (Ismail et al., 2017). They ilvolved 39 grade VII D MTs Mualimin Muhammadiyah in their research to know the effectiveness translation strategy in enhancing vocabularies. The students were taught to master the vocabularies by translating the text. They found that translation strategy could increase the students' vocabularies.

\section{CONCLUSION}

This study concluded that lecturers asking the students to identify and underline certain words to ehance the students' vocabularies mastery in the process of teaching and learning through small group discussing. The participants was then evaluate the understanding of text strategy by instructed the students to work indidually in finishing the text assignment.

This text strategy of enhancing vocabulary mastery can be as basic consideration for lecturers to be implemented in teaching vocabularies in both English department students and non-Englsh department students.

\section{REFERENCES}

Aini, S., \& Azizah, S. (2019). English Teacher's Strategy in English Teaching Learning at the Fourth Grade of SD Negeri Kowel 3 Pamekasan in 2013 Curriculum. PANYONARA: Journal of English Education, 1(1), 17-30. https://doi.org/10.19105/panyonara.v1i1 .2515 
Chung, E. (2018). Revisiting Second Language Vocabulary Teaching: Insights from Hong Kong In-Service Teachers. Asia-Pacific Education Researcher, 27(6), 499-508. https://doi.org/10.1007/s40299-0180412-3

Daugaard, H. T., Cain, K., \& Elbro, C. (2017). From words to text: inference making mediates the role of vocabulary in children's reading comprehension. Reading and Writing, 30(8), 17731788. https://doi.org/10.1007/s11145017-9752-2

Dickinson, D. K., Nesbitt, K. T., Collins, M. F., Hadley, E. B., Newman, K., Rivera, B. L., Ilgez, H., Nicolopoulou, A., Golinkoff, R. M., \& Hirsh-Pasek, K. (2019). Teaching for breadth and depth of vocabulary knowledge: Learning from explicit and implicit instruction and the storybook texts. Early Childhood Research Quarterly, 47, 341-356.

https://doi.org/10.1016/j.ecresq.2018.07 .012

Etikan, I., Musa, S. A., \& Alkassim, R. S. (2016). Comparison of Convenience Sampling and Purposive Sampling. American Journal of Theoretical and Applied Statistics, 5(1), 1-4. https://doi.org/10.11648/j.ajtas.2016050 1.11

Han, F. (2021). The relations between teaching strategies, students' engagement in learning, and teachers' self-concept. Sustainability (Switzerland), 13(9), 1-15. https://doi.org/10.3390/su13095020

Harrell, M. C., \& Bradley, M. A. (2009). Data Collection Methods. SemiStructured Interviews and Focus Groups.

Harrison, H., Birks, M., Franklin, R., \& Mills, J. (2017). Case study research: Foundations and methodological orientations. Forum Qualitative Sozialforschung, 18(1). https://doi.org/10.17169/fqs-18.1.2655

Hidayat, N. (2016). Improving Students'
Vocabulary Achievement through Word Game. Journal of English Educators Society, 1(2), 95. https://doi.org/10.21070/jees.v1i2.446

Hilal, A. H., \& Al Abri, S. S. (2013). Using Nvivo for Data Analysis in Qualitative Research. International Interdisciplinary Journal of Education, 2(2), 181-186. https://doi.org/10.12816/0002914

Kangu, F. N. (2015). Analysis of Teaching Strategies on Students' Performance in Science: A Case of Rev Muhoro Secondary School For The Deaf: Nyeri County, Kenya. Kenyatta University.

Kusumaningrum, M. A. D., \& Pertiwi, D. R. (2020). Desain Dan Uji Coba Media Pembelajaran Berbasis Video Animasi Powtoon Sebagai Sumber Belajar Pada Materi Sistem Periodik Unsur. Jurnal Inovasi Penelitian, 1(6), 1095-1106.

Mack, N., Woodsong, C., MacQueen, K. M., Guest, G., \& Namey, E. (2005). Qualitative Research Methods: A Data Collector's Field Guide (Issue January). Family Health International.

Meliana, N., Umaemah, A., \& Hidayat, H. (2018). Exploring Teacher's Strategies In Teaching Vocabulary At Grade Tenth Of Smk Sultan Agung Sumber. ELT Echo: The Journal of English Language Teaching in Foreign Language Context, 3(1), 34-46.

Mukminin, A., \& McMahon, B. J. (2013). International graduate students' crosscultural academic engagement: Stories of indonesian doctoral students on an American campus. Qualitative Report, 18(35), $1-19$. https://doi.org/10.46743/2160$3715 / 2013.1473$

Nguyen, L. (2020). A case study of Vietnamese EFL teachers' conception of language output and interaction. Journal of Language and Education, 6(1), 55-71. https://doi.org/10.17323/jle.2020.9777

Noviyanti, R., Bahri, S., \& Chairina, C. (2019). The Use of Think Bingo Game to Improve Students' Vocabulary Mastery. Research in English and 
Education Journal, 4(February), 1-8.

Ramadhan, G. R., Saukah, A., \& Andreani, S. (2021). Enhancing EFL Learners' Reading Vocabulary Acquisition through Task-Based Instruction. JoLLA: Journal of Language, Literature, and Arts, 1(2), 221-238.

Santoso, I., \& Andriyadi, A. (2019). the Use of My Dictionary Application To Improve Students' Vocabulary Mastery. ELTIN JOURNAL, Journal of English Language Teaching in Indonesia, 7(1), 35.

https://doi.org/10.22460/eltin.v7i1.p35-

42
Sari, I. P., Asahra, E. E., \& Yana, Y. (2019). Improving Students' Vocabulary Mastery Using English Song. PROJECT (Professional Journal of English Education), 2(3), 845. https://doi.org/10.22460/project.v2i6.p8 45-851

Syafrizal, S., \& Haerudin, H. (2018). the Implementation of Vocabulary Building Strategy in Teaching English Vocabulary to Young Learners. Journal of English Language Teaching, 5(1), $40-48$. 